\title{
Pilots' Suicides at Business and General Aviation
}

\section{David Hůlek ${ }^{1 *}$, Ladislav Keller ${ }^{1}$}

${ }^{1}$ Czech Technical University in Prague, Faculty of Transportation Sciences, Prague, Czech Republic

*Corresponding author: Czech Technical University in Prague, Faculty of Transportation Sciences, Horská 3, 12801 Prague, Czech Republic, Email: hulekdav@fd.cvut.cz

\section{Abstract}

A human factor is an integral part of the aviation and it becomes, together with a still improving technologies, an important component of the aviation. It cases nonstandard situations in the aviation. The goal of this paper, which deals with extreme cases of pilots' psychic failures, is to summarize and suggest possible solutions of the cases when civil pilots used an aircraft to commit suicide or when they try to commit it. There are briefly described suicide cases in the first part of the paper. The cases are from business and general aviation. The next part of the paper is about an analysis of these cases. The cases are analysed from several aspects. The authors suggest possible precautions how to prevent these cases. The paper is based on the Study of extreme cases of aviation personnel psychic failure. This study was published by a Civil Aviation Authority of the Czech Republic in 2016.

\section{Keywords}

pilots' suicides; pilots psychic failure; human factor in aviation

\section{Introduction}

People are an important part of the aviation. It is the same like in others areas. These people bring the human factor into the aviation. The human factor is an important part of the aviation since the aviation has begun to exist. Generally, the human factor is very extensive area. Many science teams deal with it around the world. This paper is about one part of the human factor. This part is the pilots' psychic failures. In this case, the psychic failures lead to a suicide or suicide attempt. 14 certain or probable suicides happened in last 50 years in business aviation. The pilots used an aircraft at all cases. There were much more cases in the general aviation. Dozens of suicides were done around the world in the general aviation [1]. For instance, the study created in the USA says that there were 25 suicides in the USA between 1983 and 1998 [2]. The situation has been quite good in the Czech Republic so far. There has not be any suicide or suicide attempt by using an aircraft in the Czech Republic according the Air Accidents Investigation Institute until now. Some experts argue that there can be up to 5 cases where the suicide by using an aircraft is probable cause of the air accident. However, no one of these cases has been defined as the suicide.

\section{Description of the pilots' suicides}

This chapter briefly describes the pilots' suicides that happened between the 70 s of the 20 th century and the 10 s of the 21 st century. For more information about the suicides, please see the mentioned references.

\subsection{Business aviation}

The table 1 describes people suicides. These people used the aircraft that were using for the business aviation. There are all suicides that have happened in the business aviation until now. This is because of the sophisticated accident analysis system 
Table 1. Summary of the pilots' suicides at the business aviation [1]

\begin{tabular}{|c|c|c|}
\hline Place & Year & Description \\
\hline Ukraine & 1972 & $\begin{array}{l}\text { The pilot stole the AN-2 and intentionally crashed into the house where he lived. The } \\
\text { reason was marital problems. }\end{array}$ \\
\hline Russia & 1976 & $\begin{array}{l}\text { The pilot stole the AN-2 and intentionally crashed into the house where his wife lived. } \\
\text { He had divorced with her. }\end{array}$ \\
\hline Columbia & 1979 & $\begin{array}{l}\text { Mechanic/pilot stole the HS- } 748 \text { and intentionally crashed into the residential district. } \\
\text { The reason was the dismissal from the employment. }\end{array}$ \\
\hline Japanese & 1982 & $\begin{array}{l}\text { The pilot switched off the autopilot during the approach, reduced the engines power, } \\
\text { changed the flight direction and the aircraft crashed. The reason was psychosomatic } \\
\text { disease. }\end{array}$ \\
\hline Russia & 1994 & $\begin{array}{l}\text { The flight engineer stole the AN- } 26 \text { and crashed after the fuel consumption. The } \\
\text { reason is not known. }\end{array}$ \\
\hline Morocco & 1994 & $\begin{array}{l}\text { The ATR- } 42 \text { crashed in the Atlas mountains. It happened shortly after the take-off. } \\
\text { The captain turn off the autopilot at FL160. Then he started to descent and crashed. } \\
\text { The reason was marital problems. }\end{array}$ \\
\hline Argentina & 1995 & $\begin{array}{l}\text { The co-pilot manipulated with the main door open mechanism during the flight. He } \\
\text { dropped out after the door had opened. The reason was either suicide or unfortunate } \\
\text { accident. }\end{array}$ \\
\hline Indonesia & 1997 & $\begin{array}{l}\text { The captain started to descent and crashed during the flight. The co-pilot was not in } \\
\text { the cockpit. The reasons were working and financial problems. }\end{array}$ \\
\hline Botswana & 1999 & $\begin{array}{l}\text { The captain stole the ATR- } 42 \text {. It happened after he had received the ban on flying for } \\
\text { health reasons. He hit the other two parked planes. }\end{array}$ \\
\hline USA & 1999 & $\begin{array}{l}\text { The aircraft started to descent and crush after the take-off. This was the intentional } \\
\text { act of the second pilot. The reason is not known. Supposedly, it was the last flight } \\
\text { before the dismissal. }\end{array}$ \\
\hline USA & 2012 & $\begin{array}{l}\text { The pilot tried to steal the aircraft. He hit the building during the taxiing. The he shot } \\
\text { himself. The reasons were sorrow and girlfriend's death. }\end{array}$ \\
\hline Namibia & 2013 & $\begin{array}{l}\text { The pilot started to descent and crashed intentionally. This happened after the co-pilot } \\
\text { had left the cockpit. The reasons were family problems and death in the family. }\end{array}$ \\
\hline Indic ocean & 2014 & $\begin{array}{l}\text { The loss of contact with the aircraft. It is assumed that the aircraft crashed into the } \\
\text { Indic ocean. The experts mean that this war the intentional act one of the pilots. } \\
\text { Probably, it was the captain. Probable reason is the insurance fraud. }\end{array}$ \\
\hline France & 2015 & $\begin{array}{l}\text { The co-pilot locked the cockpit, started to descent and crashed. This happened after } \\
\text { the captain had left the cockpit. The co-pilot had health problems. This problems } \\
\text { should be the reason for ending the pilot career. }\end{array}$ \\
\hline
\end{tabular}

that is used in the business aviation. The table shows the place of the suicide or the suicide attempt, year of the suicide and brief description for each case.

\subsection{General aviation}

There were dozens of suicides in the general aviation. It is not possible to mention and analyse all of them. There is used the FAA study in the paper. The study was made from 2003 to 2012 [3]. The table 2 shows these cases.

\section{Analysis of the suicides}

This chapter analysis the suicides' process and their causes. The chapter is divided into the business and general aviation again.

\subsection{Business aviation}

First, the causes from the business aviation are going to be analysed. The reason for suicide was the loss of an employment in the absolute majority of the cases. The other two reasons were personal problems respectively personal frustrations. It was unknown reasons in some cases too. The unknown reasons can be only estimated. If the suicides are analysed from their process, it can be find out that the pilot stole the empty parked aircraft and done the act. This is in effect in approximately half of the cases. Otherwise, there were more people in the aircraft. There was only pilot which want to suicide or there were either all pilots or other crew member in the cockpit.

\subsection{General aviation}

It is obvious from the analysis of the US pilots' suicides in the general aviation that in almost all cases the suicide was 
Table 2. Summary of the US pilots' suicides at the general aviation between 2003 and 2012 [3]

\begin{tabular}{ll}
\hline Order & \multicolumn{1}{c}{ Description } \\
\hline 1 & The pilot shortly after the take-off did 4 left turns, started to descent and crash into \\
the wooded area. The doctors defined this accident as a suicide. \\
The pilot took-off with the PA-28-235. Shortly after the take-off the aircraft hit the \\
ground. The reason was pilot's psychic problems. The pilot had depressions. He had \\
hospitalized because of that before. The pilot said that he commits suicide. \\
The pilots took-off with the Beechcraft A-36 and he hit the hill after the circling \\
around it. The reasons were psychic and alcohol problems. The pilot said that he \\
commits suicide. \\
The pilot crashed with Robinson 44 helicopter. It was at an open landscape. The \\
reason was that the pilot did not handle the rejection of a beloved woman. The pilot \\
said that he commits suicide. \\
The pilot kidnaped his child and hit the mother-in-law's house. The reason was \\
dispute about child custody. \\
The pilots crashed after 5 hours of the flight. The reason was the breakup with \\
girlfriend. The pilot said that he commits suicide. \\
The pilot intentionally hit the administrative building of the Internal Revenue Service. \\
The reason was the dispute with the company. \\
The pilot intentionally felt down into the Atlantic ocean. The reasons were personal \\
problems and suicidal tendencies. The pilot said that he commits suicide.
\end{tabular}

planned and the pilots' behaviour suggested that they were going to kill themselves. The information about the suicide were given by oral statements or by goodbye letters before the act. The reasons were mostly psychic or personal (social) problems.

\section{Possible precautions}

There are proposed precaution that could reduce risks connected with the pilots' suicides in this chapter. The chapter is divided into the business and general aviation as well as the previous chapters.

\subsection{Business aviation}

As it is mentioned in the previous chapter, the significant reason for the suicide is the loss of the employment in general aviation. A solution of this situation is not simple. The dismissal of the employees is part of the working process. There exist some precautions that can be applied. Then, the risk of the suicide could be lower. Organizational measures are the first precaution. One of them can be a golden handshake. A suitable golden handshake can help to low the frustration from the loss of the employment. Social programs are the other precaution. The pilots could get into the other position in their old company or the company could help them with searching a new employment, make recommendations to other companies and so on. The dismissal was announced to the pilot just before the flight in one described case. This is a fatal error of the company's Personnel Department. A right timing of the dismissal notification is another precaution. It could help to low the risk too. The frustration and problems were the next significant reason. This reason is generally difficult to prevent [4]. Though the business pilots have the medical examination every year [5], the psychic examination is not compulsory. The psychic imagination does not do in some countries. The possibility how to prevent this reason is to implement the compulsory psychic examination during the medical examination that the pilots must have every year.

It was find out during the analysis that the pilot stole the aircraft in the half of the cases. The precaution against the theft is obvious. The parked aircraft must be secured not to be able to steal them. Both the parking and the airport security procedures should be better. The other group of the suicides were done by the intentional aircraft crash. The pilot was in the cockpit alone in some cases. He locked himself in some cases too. The possible precaution is to ensure that there always will be minimally two persons in the cockpit. If the one pilot leave the cockpit, the one crewmember (for instance cabin crew) will replace him/her. The locked door is the problem. This precautions has implemented to avoid entry of the terrorists into the cockpit. If there is some option how to open the locked door, the antiterrorist precaution will lost its meaning. It will be necessary to set the priorities and to choose the best option.

\subsection{General aviation}

It is obvious from the analysis that the psychic problems or troubles precede the pilots' suicides in the general aviation. The precaution is not simple. The general aviation pilots have medical examination every 5 years. The medical examination is earlier ( 2 or 1 year) in some cases [5]. The psychic examination is not compulsory. The psychic problems and failures may not be detected. The precaution is to manage the compulsory psych tests and examination. The psychic examination could detect the problems that cause addiction to 
the suicide. The other precaution is the shorter examination then 5 years.

\section{Conclusion}

The area of the pilots' suicides cannot be omit. As it is evident from the number of the suicides in business and also general aviation. 2 new air accident confirm this statement. This new accidents happened during the work on this paper (a half of the August 2018). Neither of this two accidents have been investigated yet but the circumstances show that it was the suicide in both cases [6]. 14 certain or probable suicides happened in last 50 years in business aviation. In some cases the pilots kill themselves together with many innocent people. Hundreds of people lost their lives during the pilots' suicides. It is obvious that this area of the human factor should not be neglected. All participated parties as airliners, training organizations, airport operators and so on should try to prevent the pilots' suicides.

\section{References}

